\title{
Comparison of monsoon variations over groundwater hydrochemistry changes in small Tropical Island and its repercussion on quality
}

\begin{abstract}
Study on the spatial and temporal distribution of groundwater hydrochemistry in the small tropical islands is important as their insular character may expose the groundwater aquifer to too many sources of pollution, especially salinization. A total of 216 groundwater samples were collected from the monitoring boreholes during two different monsoon seasons; preand post-monsoon. As overall, data of groundwater concentration illustrated a trend of $\mathrm{Ca}>$ $\mathrm{Na}>\mathrm{Mg}>\mathrm{K}$ and $\mathrm{HCO} 3>\mathrm{Cl}>\mathrm{SO} 4$ dominations with the major finding of two different groundwater types. Pre-monsoon reported Na-HCO3 and $\mathrm{Ca}-\mathrm{HCO} 3$ types while postmonsoon were only dominated by the $\mathrm{Ca}-\mathrm{HCO} 3$ type. The statistical analysis shows the in situ parameters (Temp, pH, EC, Salinity, DO, TDS and Eh) and major ions ( $\mathrm{Ca}, \mathrm{Mg}, \mathrm{Na}, \mathrm{K}$, $\mathrm{HCO} 3, \mathrm{Cl}$ and $\mathrm{SO} 4)$ were strongly correlated with the monsoon changes ( $<<0.01$ ). From the analysis, its reveals that the seasonal changes have significantly affects the groundwater composition. While, the analytical calculations of the ionic ratio $(\mathrm{Na}$ vs. $\mathrm{Cl} ; \mathrm{Cl} / \mathrm{HCO} 3$ vs. $\mathrm{Cl}$; $\mathrm{Ca}+\mathrm{Mg}$ vs. $\mathrm{SO} 4+\mathrm{HCO} 3)$ describes the groundwater is influenced by the cation exchanges processes, simple mixing and water-rock interaction. Saturation indices of carbonate minerals shows strong correlationship $(\mathrm{p}<0.01)$ with Ca constituent indicating solubility on minerals, which led to dissolution or precipitation condition of water. Results of present study contribute to a better understanding of a complex groundwater system and the hydrochemical processes related.
\end{abstract}

Keyword: Groundwater hydrochemistry; Groundwater; Tropical islands; Monsoon 